\title{
Probing the mind of God: divine beliefs and credences
}

\author{
Elizabeth Jackson ${ }^{1 *}$ (D) and Justin Mooney $^{2}$ \\ ${ }^{1}$ Department of Philosophy, Ryerson University, 350 Victoria Street, Toronto, Ontario, Canada M5B \\ 2K3 and ${ }^{2}$ Department of Philosophy, University of Massachusetts Amherst, 151 Hicks Way, E305 \\ South College, Amherst MA, 01003, USA \\ *Corresponding author: Elizabeth Jackson, email: lizjackson111@gmail.com
}

(Received 30 June 2021; revised 24 September 2021; accepted 25 September 2021)

\begin{abstract}
Although much has been written about divine knowledge, and some on divine beliefs, virtually nothing has been written about divine credences. In this article we comparatively assess four views on divine credences: (1) God has only beliefs, not credences; (2) God has both beliefs and credences; (3) God has only credences, not beliefs; and (4) God has neither credences nor beliefs, only knowledge. We weigh the costs and benefits of these four views and draw connections to current discussions in philosophical theology.
\end{abstract}

Keywords: belief; credence; omniscience; open theism; divine mental states; divine knowledge

\section{Introduction}

God has beliefs. Many theist philosophers would affirm this without thinking twice. It's commonly thought that for every true proposition, God believes it, and for every false proposition, God disbelieves it. However, recently, some epistemologists have argued that the tripartite belief framework - on which, for every proposition $p$, we have three choices: believe $p$, withhold belief that $p$, or disbelieve $p$ - doesn't tell the full story. This is because we're more confident in some things we believe than in others. Suppose Sam believes both that $2+2=4$ and that it will rain tomorrow; her attitude towards those propositions probably isn't exactly the same. Many epistemologists capture this difference by appealing to credences. ${ }^{1}$ Credences are a measure of one's confidence in a proposition on a scale from $[0,1]$, where 1 represents absolute certainty that some proposition is true, and 0 represents absolute certainty that it is false. Sam's credence that $2+$ $2=4$ is quite close to 1 , but her credence that it will rain tomorrow is 0.8 . Credences capture these fine-grained features of cognitive states that beliefs cannot. ${ }^{2}$ Here, we'll generally take both beliefs and credences to be propositional, representational mental states. Beliefs, however, represent the world in a coarse-grained way, whereas credences represent it in a fine-grained way.

When it comes to divine mental states, much has been written on divine knowledge (especially how we might reconcile divine foreknowledge and human freedom) and a bit has been written on the nature of God's beliefs (especially in attempts to understand divine omniscience). However, we are not aware of any discussions of whether God has

(c) The Author(s), 2021. Published by Cambridge University Press. This is an Open Access article, distributed under the terms of the Creative Commons Attribution licence (http://creativecommons.org/licenses/by/4.0/), which permits unrestricted re-use, distribution and reproduction, provided the original article is properly cited. 
credences. This article, then, aims to fill that lacuna. Our goal is to lay out, compare, and evaluate various views on whether God has beliefs, credences, both, or neither.

We'll consider four views of divine doxastic attitudes: the view that God has only beliefs, the view that God has both beliefs and credences, the view that God has only credences, and finally, the view that God has neither beliefs nor credences, only knowledge. The view that God has both beliefs and credences further divides into four views. Each takes different stances on whether one attitude reduces to the other: the view that divine credences reduce to divine beliefs (divine belief-first); the view that neither divine credences nor divine beliefs reduce to the other (divine dualism); the view that divine beliefs reduce to divine credences above a threshold $t$, where $t$ is less than 1 , and usually greater than 0.5 (divine threshold view); and the view that divine beliefs reduce to divine credences of value 1 (divine belief-is-credence-1). This plus the views in the other three sections leaves us with seven views of divine doxastic attitudes; we'll discuss arguments for and against each. We'll also consider the question of what, if God has credences, those credences might be. Are all of God's credences extreme, that is, 0 and 1? Might it ever be appropriate to ascribe non-extreme credences to God? Ultimately, we think that if God has mental representations, then divine belief-first and divine belief-is-credence- 1 are most plausible; however, the knowledge-only view is also a live contender. But our main goal is to highlight some of the pros and cons of each view.

Before we begin, we'll clarify the concept of God we're concerned with in this article. We will understand God in the way that God has normally been understood in the Abrahamic theological traditions. In particular, we will assume that God is a perfect being. More controversially, we will take the thesis that God is a perfect being to entail, not merely that God has the greatest overall combination of great-making properties, but also that God has each great-making property to its maximally valuable degree. ${ }^{3} \mathrm{We}$ assume that one of God's great-making properties is cognitive perfection, and we will also assume that cognitive perfection entails omniscience. We will not presuppose any particular account of omniscience, nor will we assume that omniscience exhausts cognitive perfection. As Linda Zagzebski (2008: 232) has observed, depending on how omniscience is defined, there may be more to cognitive perfection than omniscience. For example, later in the article, we will consider the view that a cognitively perfect being not only knows everything, but knows everything via direct awareness. So one question that will concern us in what follows is how well (or poorly, as it may be) different views on divine beliefs and credences cohere with the thesis that God is cognitively perfect.

\section{The belief-only view}

The first view we'll consider is the view that God has only beliefs and no credences. What might motivate this view? Let's first consider an argument that God has beliefs. On the classic understanding of omniscience, for every proposition, God either knows that it is true or knows that it is false (Wierenga (2011), 130). However, knowledge is very commonly analysed as justified true belief, plus an anti-Gettier condition. Many epistemologists are on board with this analysis, although there is strong disagreement on how exactly to understand the justification and the anti-Gettier conditions. ${ }^{4}$ Even knowledgefirsters, who deny that knowledge should be reduced to belief plus other factors, nonetheless maintain that knowledge entails belief - it's just that, on their view, knowledge is more fundamental than belief (see Williamson (2000)). ${ }^{5}$

Given that divine knowledge entails belief, plus the doctrine of omniscience, it follows that God has beliefs: for every true proposition, God believes (and knows) $p$, and for every false proposition, God believes (and knows) not- $p$. (When we discuss the knowledge-only view, we'll see reasons to question that divine knowledge entails belief.) 
Recall that the view in question isn't merely that God has beliefs, but that God has beliefs and no credences. It's difficult to find an argument for this in the literature, as, when it comes to divine epistemic states, the most attention by far has been given to God's knowledge. While many seem to assume that God has beliefs, that's often the extent of the discussion. Wierenga $(2011,132)$ notes: 'with only a few exceptions, philosophers have not inquired into the status of God's beliefs or the nature of his justification'. Even less attention has been paid to the question of whether God has credences. We suspect many who assume God has beliefs haven't even considered whether God might also have credences.

But we can speculate. What could motivate that God has beliefs and no credences? One reason to think God has only beliefs is because divine credences seem superfluous. Given that God is a perfect being, God would not have superfluous mental states. And one might think that divine credences are superfluous because God has perfectly accurate beliefs about every single proposition. It's not clear that credences, in addition to perfectly accurate beliefs, would be useful to God or helpful in divine decision making. It's also unclear that credences would contribute to divine cognitive perfection in any way. Furthermore, credences don't seem necessary to understand omniscience. We can define omniscience in terms of divine belief and knowledge, and this definition seems to be precise and complete (Wierenga (2011)). What would divine credences add?

While we think this line of reasoning is prima facie compelling, upon further scrutiny, there are several good reasons to think that God has credences. We now turn to those reasons.

\section{The belief-and-credence view}

There are at least three reasons to think that God has credences in addition to beliefs. The first begins with the observation that humans have credences in addition to beliefs. Holton (2014) and Horgan (2017) come closest to defending (human) credal-eliminativism; they express scepticism that we have precisely point-valued credences. They are nonetheless quite open to the idea that we have various levels of confidence in propositions (or what Holton calls 'partial beliefs'). As mentioned above, we're understanding credences as a measure of levels of confidence, so on their view, humans would have credences. And credences need not always be precisely point-valued; many formal epistemologists are open to the possibility and rationality of imprecise credences (Weisberg 2015: sec. 2; Bradley 2019). As Jackson (2020-a: 2) says: 'Depending on how broad one's notion of credence is, then, virtually no-one defends credence-eliminativism. After all, we are more confident in some of our beliefs than in others, and it is not obvious how to capture this with a belief-only ontology.' Thus, there's good reason to think humans have credences.

The fact that humans have credences is a reason to think that God has credences, too. Granted, God is a perfect being and so is different from humans in many ways. But, at least in the Judaeo-Christian tradition, humans are made in God's image, which suggests some robust similarities between human beings and God. Moreover, God is also a personal being with a mind, just like we are. So, at a certain level of abstraction, God is the same sort of thing that we are, and therefore we have a reason to expect God to be like us in many ways - albeit only ways that do not comprise God's perfection. We think these considerations give us a defeasible reason to think that, if we have credences, then God does too, provided that having credences is not an imperfection. So is having credences an imperfection? That is far from clear. A proponent of the belief-only view who thinks that credences would be superfluous for God might claim that having superfluous mental states is an imperfection. But our next two reasons for thinking that God has credences cast doubt on their superfluity. 
The second reason to think that God has credences is that divine credences may be required to ensure that God can act on God's beliefs. Plausibly, it's not always rational to act on any justified belief (see Brown 2008). For example, even if Sam has a justified belief that she was born in Oklahoma, it would not be rational for her to bet on this belief in a scenario where she has little to gain (e.g. \$10), and much to lose (e.g. 30 years of torture). So one might think that, in order to ensure that God can act on all of God's beliefs, God needs sufficiently high, rational credences in the propositions that God believes.

Here's a third reason to think God has credences, previewed in the introduction. Let's suppose some subject $\mathrm{S}$ believes some proposition, $p$. If this is all we know, that doesn't tell us the full story about S's epistemic state. Some beliefs we have excellent evidence for (e.g. $1+1=2)$. Other times, we may have worse evidence, but it's still sufficient for belief. For example, Sam believes her car is parked in her driveway even though she hasn't seen it since last night. She believes her brother had a bagel for breakfast yesterday, as he eats bagels almost every single day. She believes that her coffee is cold, even though she hasn't touched her coffee cup recently. In all these cases, Sam rationally believes the proposition in question, but her evidence is worse than her evidence in favour of basic mathematical truths. It seems like we need another attitude that can capture these evidential differences. Hence, many epistemologists posit credences, which are significantly more fine-grained than beliefs.

A similar line of reasoning applies in the divine case. If all we know is that God believes $p$, the same issue arises; this doesn't fully specify God's epistemic state concerning $p$. God's evidence isn't just good enough for belief - it's perfect. Due to this perfect evidence, God is certain about the propositions God believes. However, it's not clear how the belief-only view can capture God's certainty, since a mere belief underdetermines one's level of evidence and thus one's level of confidence. Positing that God knows these propositions probably won't help, either, since most epistemologists maintain that knowledge doesn't require perfect evidence or certainty (see, e.g. DeRose (1995), 4-5; Hawthorne (2004), 126-131).

One might respond to the above arguments by positing that, in addition to beliefs about bare propositions, God also has beliefs about the probability of those propositions. For every true proposition, God believes $p$ and God believes that the probability of $p$ is 1 ; for every false proposition, God believes not- $p$ and God believes that the probability of $p$ is 0 . This view parallels what's often known as the belief-first view of the relationship between belief and credence (see Moon and Jackson 2020). This view can explain how God is maximally confident in all of God's beliefs. However, this view is normally not taken to be one on which there are no credences at all. Instead, defenders of the belief-first view maintain that there are credences, but those credences reduce to beliefs, often by adding something to the content of what is believed (probabilistic modifiers, epistemic modals, etc.). In other words, the belief-first view is credal-reductionist, but not credal-eliminitivist. For example, in the human case, my 0.5 credence that this coin will land heads is my belief that the probability the coin will land heads is 0.5 . Similarly, God's credence of 1 that this coin will land heads is God's belief that the probability the coin will land heads is 1 . So this is a view on which God has both beliefs and credences; divine credences are just, more fundamentally, beliefs.

On an alternative view, God has both beliefs and credences, but divine credences don't reduce to divine beliefs. Credences are sui generis, and not simply (e.g.) God's beliefs about probabilities. This second view, however, leaves open whether there might be a reduction in the other direction: does God's belief that $p$ reduce to God's credence in p? Maybe God's fundamental epistemic state is credence, but God has beliefs in virtue of having sufficiently high credences in certain propositions. The general view that reduces belief to credence is normally called the credence-first view, which divides into two other views. First is the threshold view, on which belief is credence above some threshold, where the threshold 
is less than 1 (but normally greater than 0.5 ). For example, if the threshold is 0.75 , then beliefs reduce to credences of 0.75 or higher. Then, if God has a 0.7 credence it will rain tomorrow, God does not believe it will rain tomorrow, but if God has a 0.8 credence it will rain tomorrow, God believes it will rain tomorrow. Second, there's the belief-is-credence-1 view, on which belief is credence 1, but if God has any credence short of 1 in $p$, God doesn't believe $p$. For example, God's belief it will rain tomorrow reduces to a credence of 1 that it will rain tomorrow. (On some ways of distinguishing the views, the belief-is-credence-1 view is a version of the threshold view; we've given the views distinct labels for the ease of reference.) A final view, the dualist view, is that God has both beliefs and credences, but neither reduces to the other; divine beliefs don't reduce to divine credences, and divine credences don't reduce to divine beliefs.

In sum, there are four versions of the view that God has both beliefs and credences:

Divine belief-first: God has both beliefs and credences, and God's credences reduce to God's beliefs.

Divine threshold view: God has both beliefs and credences, and God's beliefs reduce to God's credences above some threshold less than 1.

Divine belief-is-credence-1 view: God has both beliefs and credences, and God's beliefs reduce to God's credences of 1 .

Divine dualism: God has both beliefs and credences, and God's beliefs and God's credences are irreducible.

How might we adjudicate between these views? Ultimately, this will depend on both one's commitments in epistemology (e.g. the functional roles of belief and credence) and in philosophical theology (e.g. whether God has non-extreme credences). We'll discuss some costs and benefits of each view. We'll ultimately conclude that both divine dualism and the divine threshold view have some unattractive consequences, and divine belief-first and belief-is-credence-1 are more plausible.

As we explore these views, we will need to consider both the possibility that all of God's credences are extreme (i.e. either 1 or 0 ), and the possibility that some of God's credences are non-extreme. Initially, it might seem that a cognitively perfect being should have only extreme credences: credences of 1 in all true propositions and credences of 0 in all false propositions. But there is at least one major strand of philosophical theology that is amenable to the idea that God has non-extreme credences, namely, open theism.

The distinctive commitment of open theism is that God does not know contingent propositions about the future which are not at present causally determined. ${ }^{6}$ Typically, open theists say that this limitation on God's knowledge is compatible with omniscience because it is metaphysically impossible for an infallible being to know future contingents and omniscience does not require knowing things that it is metaphysically impossible for God to know (e.g. Hasker (1989), 187; van Inwagen (2008); Swinburne (2016), 182-197). An open theist might say that God has non-extreme credences in future contingents just as we seem to have non-extreme credences in future contingents. Which non-extreme credences would God have? Since God is cognitively perfect, God would have whichever non-extreme credences it is rational to have. According to David Lewis's (1980) Principal Principle, rational credences match known objective chances. Therefore a cognitively perfect being's credence in a future contingent, $p$, would match the objective chance that $p$ is true.

So as we consider the different views on God's beliefs and credences, we will keep our eye both on the possibility that all of God's credences are extreme and on the possibility that God has non-extreme credences that conform to the Principal Principle. 


\section{Divine belief-first}

First, consider the belief-first view. Many of the objections to the belief-first view in the human case gain traction because of a human limitation or lack. Consider a classic objection: many children and animals don't have the concept of probability, and thus cannot form probability-beliefs, but nonetheless can have credences. For example, a dog might have a higher credence that Bob will feed him than that John will feed him, and thus beg Bob for food first (see Frankish 2009). Recently, Jackson (Forthcoming) has raised a second objection: in cases of very complex, barely-graspable propositions, one can form credences about them but cannot form the beliefs required for a belief-first view (e.g. I can grasp, and thus form a 0.5 credence in the proposition that <he said that she said that she knows that he believes that she is mad at him> but cannot believe that <the probability that he said that she said that she knows that he believes that she is mad at him is $0.5>$, since this latter proposition is too complex for me to grasp). Both of these objections to the belief-first view do not apply in the divine case. Since God is cognitively perfect, so God wouldn't lack concepts, nor would there be propositions that God couldn't grasp.

The other major objection to the belief-first view involves the interpretation of probability in these beliefs. Christensen (2004, 19-20) pioneered this objection, arguing that frequentist and subjectivist interpretations won't work. Belief-firsters have argued that credences should be understood as beliefs about epistemic probability (i.e. the probability of $p$ given your evidence; see Easwaran (2015), 659, Sturgeon (2020), ch. 9, and Moon and Jackson (2020)). In the divine case, one might think that God's credences are beliefs about objective chances. However, we prefer epistemic probabilities. Suppose you think the world is indeterministic, but God has foreknowledge. Then God has Lewisian 'inadmissible evidence', that is, information from the future about how chancy processes will turn out. (Lewis's original statement of the Principal Principle makes an exception for cases where an agent has inadmissible evidence.) So God's credences will not match the objective chances, and thus will come apart from God's beliefs about the objective chances. However, because God has the inadmissible evidence, God's beliefs about epistemic probabilities will match God's credences. Then, God's credences track God's beliefs about epistemic probabilities, not God's beliefs about objective chances.

Another advantage of divine belief-first is that, by reducing credences to beliefs, it resembles the belief-only view in holding that only beliefs are fundamental. This is significant if Schaffer (2015) and Bennett (2017, 220-225) are right that fundamental parsimony, rather than parsimony simpliciter, is the kind of parsimony that counts in favour of a theory.

Moreover, the divine belief-first view can accommodate different views on what credences God has. For example, maybe future contingents have non-extreme objective probabilities. Open theists have been known to say that God knows the objective probabilities of future contingents and takes them into account when providentially governing the world (Hasker (1989), 188; Boyd (2001), 25). And if God knows those probabilities, and knowledge entails belief, then God has beliefs about them. On the divine belief-first view, those beliefs turn out to be non-extreme credences.

So the divine belief-first view has a lot going for it. It avoids standard objections to its human counterpart; it retains the parsimony of the belief-only view; and it easily accommodates non-extreme credences.

\section{Divine credence-first}

What about the credence-first view, on which God's beliefs reduce to God's credences? First, unlike the credence-only view (discussed later), this view can capture the intuitive 
idea that God has beliefs, which also preserves divine-human symmetry (since it's plausible that humans have beliefs). At the same time, divine credence-first still preserves divine cognitive simplicity at a fundamental level (since credences are the only fundamental existents).

Recall we discussed two versions of the credence-first view: the threshold view and the belief-is-credence-1 view. One of the most common objections to the threshold view involves what the threshold for belief should be, as many potential thresholds for belief look ad hoc (for discussion, see Lee (2017); Shear and Fitelson (2019)). While the belief-is-credence-1 view doesn't look ad hoc (Greco (2015) calls this view 'the simple view'), this view runs into problems in the human case - for instance, we're more confident in some of our beliefs than in others, we believe things that we aren't maximally certain of, and we should not take bets at extraordinary odds on all our beliefs, but according to decision theory, we should take such bets on propositions in which we have credence 1 .

Suppose first that God has exhaustive foreknowledge, so all of God's credences are 1 or 0. If God's credences are all extreme, the problems commonly raised for the belief-ascredence-1 don't apply: God isn't more confident in some of God's beliefs than in others and God doesn't believe things without maximal certainty. Due to this certainty, God can confidently 'bet' on all of God's beliefs. Thus, if God's credences are all extreme, it's reasonable to think that divine beliefs reduce to divine credences of 1.

Suppose instead that open theism is correct and God does not have exhaustive foreknowledge. Interestingly, then, there is a different reason to prefer the belief-is-credence-1 view to the threshold view. ${ }^{8}$ To see this, consider again the view that God has non-extreme credences in future contingents. Suppose the threshold for divine belief is some value less than 1, such as 0.9. And suppose the objective chance that Sam will eat Cheerios tomorrow is 0.999 , because Sam eats Cheerios almost every day and tomorrow is shaping up to be an ordinary day. Given that a cognitively perfect being's credence in a future contingent will match the objective chance that the future contingent is true, God has a credence of 0.999 that Sam will eat Cheerios for breakfast tomorrow. Since the divine threshold view entails that God believes any future contingent with an objective chance above the threshold, it follows that God believes that Sam will eat Cheerios for breakfast tomorrow. In that case, God's belief that Sam will eat Cheerios tomorrow is fallible, since there is a chance, however small, that she won't. Thus, God risks having a false belief, which compromises omniscience and makes God fallible. Therefore, to avoid the consequence that God could have a false belief, the threshold view should be rejected (where $t<1$ ).

To be clear, our claim is not that God should have some credence other than 0.999 in the proposition that Sam will eat Cheerios tomorrow. That is, after all, the accurate credence for God to have in this situation. The problem is that, given the divine threshold view, God also believes Sam will eat Cheerios tomorrow. Thus, in this case, having an accurate credence is incompatible with having only infallible beliefs. Since a cognitively perfect being would have only accurate credences and only infallible beliefs, the divine threshold view is incompatible with divine cognitive perfection.

Here's a possible way to save the divine threshold view from this objection. ${ }^{9}$ Suppose, contrary to open theism, that God foreknows what Sam will do. Then God has inadmissible evidence about what Sam will do: God can see that Sam will in fact eat Cheerios. If God's belief about what Sam will do tracks this inadmissible evidence, but God's credence does not, then that belief may be infallible even if God's credence matches the 0.999 objective chance that Sam will eat Cheerios. This is a way out, but it comes at a cost. It's a little odd to think that God's confidence that Sam will eat Cheerios is not increased by seeing her eating Cheerios in the future. It's even odder to think that God's credences are not affected by this evidence even though God's beliefs are affected by it. 


\section{Divine dualism}

Finally, consider the dualist view, on which God has both beliefs and credences, and neither reduces to the other. A common objection to the dualist view is Kaplan's (1996) Bayesian challenge. Kaplan asks: why would we have both a credence in $p$ and a belief that $p$ ? Positing both seems superfluous. Unless each attitude is given a clearly spelled out role, it's not clear that we should posit two, irreducible epistemic attitudes toward the same propositions.

Dualist answers to the Bayesian challenge fall into two camps; each takes a different position on the role for belief. On the first view, beliefs are a heuristic, useful for simplifying reasoning. For example, Julia Staffel (2019) argues that beliefs simplify reasoning by ruling out small error possibilities. In some contexts, it's appropriate to treat a claim in which one has a high credence as true, as this makes one's reasoning process much easier, without a substantial loss in accuracy (see also Tang 2015; Jackson 2019). Reasoning with credences does not rule out these error possibilities, so high credences cannot simplify reasoning in the way that beliefs can. Thus, the role for belief is simplifying reasoning, which is useful in low-stakes situations or when we have to make a quick decision, and the role for credence is accuracy, which is useful in high-stakes situations when precision is more important.

On the second view, beliefs are not a heuristic, but play roles that high credences cannot: for example, they allow us to take a stand and have a view of the world (Ross \& Schroeder 2014). Lara Buchak argues that beliefs are essential to our moral judgements, including our practices of praise and blame. High credences can be based on statistical evidence, but statistical evidence isn't an appropriate basis for blame - if either Jake or Barbara stole my cell phone, I shouldn't blame Jake simply because I know (supposedly) that men are $10 \times$ more likely to steal cell phones than women. Thus, instead of relying on credences, we form a belief about whether someone is guilty and then blame them in proportion to their crime (Buchak 2014). ${ }^{10}$ Finally, beliefs play a role in knowledge; as discussed above, knowledge is often understood as unGettiered justified true belief. For each role, dualists argue that high credences cannot play the relevant role: high credence doesn't allow us to take a stand, cannot play the relevant role in our moral judgements, or amount to knowledge (see Jackson 2021). On the other hand, credences play another role, which beliefs are too coarse-grained to play: perhaps in tracking our exact level of evidential support, or providing accuracy, as discussed above.

The merits of divine dualism will depend, in part, on the role that belief plays. If beliefs are merely a heuristic - an accurate-enough tool to simplify the reasoning process - then a cognitively perfect agent would not have beliefs. If beliefs instead play one of the other roles - in our moral judgements, in our knowledge, or enabling us to take a stand - then divine dualism is more plausible. However, the dualist needs to argue not only that divine beliefs play these roles, but also that divine credences cannot. And in the divine case, these roles can be played by extreme credences. A credence of 1 in $p$, for example, takes a stand on the truth of $p$, and can be a proper basis for moral judgement in Buchak's (2014) sense (because, for example, if I know that $100 \%$ of people who steal cell phones are men, and thus have a credence of 1 that Jake did it, this seems like an appropriate basis on which to blame Jake for theft; see Jackson (2020-b), 5081). If God has extreme credences in all the propositions God believes, then the primary motivation for dualism appears unsuccessful - there's no reason to posit beliefs as fundamentally distinct from credences, when God's extreme credences can play the relevant roles.

If instead we say that God has non-extreme credences in some propositions, however, then divine beliefs in those same propositions may not be superfluous. But unfortunately, as we saw when we discussed the divine threshold view, they will be fallible. Plausibly, God 
will only believe propositions in which God has non-extreme credences. But if God has a non-extreme credence in a proposition, then there is some chance that it is false, so there is some chance that God's belief in that proposition is false. So non-extreme credences save divine dualism from one problem (belief superfluity) only to lead it straight into another (belief fallibility). We conclude that divine dualism is not a promising view of God's beliefs and credences.

\section{The credence-only view}

Let's now consider the view that God has only credences, and no beliefs. How might we motivate this view? We might start with the reasons God has credences, discussed above that is, humans are made in God's image and have credences, and divine credences (unlike beliefs) can capture God's precise amount of evidence for various propositions. Presumably, divine credences are perfectly accurate. (So, for example, if God's credences are all extreme, God has a credence of 1 in all true propositions, and God has a credence of 0 in all false propositions.) If God has perfectly accurate credences, this raises the following question: what would divine beliefs add? This question is especially pressing if divine extreme credences can play the typical roles given for belief.

Furthermore, it seems one could give a reasonable account of omniscience in terms of perfectly accurate credences. God is maximally confident that every true proposition is true, and maximally confident that every false proposition is false. This is arguably an even better account of omniscience than the belief-only view, on which God's degrees of confidence are unspecified.

One might wonder, however, whether this view could capture the idea that God knows things. As noted above, intuitively, belief, not credence, is a part of knowledge. However, the defender of divine credence-only could appeal to Sarah Moss's $(2013 ; 2018)$ argument that credences can amount to knowledge. Moss argues that credences can constitute knowledge (or at least be knowledge-like) - credences can have properties such as factivity, safety, sensitivity, and even be unGettiered. For example, Moss's way of understanding factivity is as follows: the inference from ' $\mathrm{S}$ knows that $p$ ' to ' $p$ ' is valid. If one's credence in $p$ amounts to knowledge, then one can infer ' $p$ ' from S's credence in $p$. In these cases, credences can meet the factivity condition of knowledge (Moss (2013), 12-13). When credences are factive and meet other conditions, they amount to what Moss calls 'probabilistic knowledge'. A defender of the divine credence-only view could borrow from Moss's account and argue that God's credences satisfy the conditions for knowledge (as they are factive, unGettiered, etc.). Then, even if God has only credences, God can nonetheless know things. (This story seems especially easy to tell if all of God's credences are extreme.)

This view of divine knowledge may be especially attractive to the open theist, because it may give the open theist a response to a long-standing objection to her position. The objection claims that, on open theism, we seem to be able to know things that God cannot know (Stewart (2019), Kvanvig (1986), 18). For example, an ordinary human being can know that Sam, who invariably eats Cheerios every day, will eat Cheerios tomorrow. But the objective chance that she will eat Cheerios tomorrow is less than 1 . Therefore, if God believes that Sam will eat Cheerios tomorrow, there is a chance that God's belief will turn out to be false. Since God is infallible, it follows that God does not believe that Sam will eat Cheerios tomorrow. And if knowledge entails belief, what is not believed is not known either. So an ordinary human can know something that God doesn't, despite the fact that humans are far from cognitively perfect, and yet God is cognitively perfect. That's unpalatable.

But we've suggested that, to give an account of omniscience, a credence-only theorist might adopt Moss's view that credences amount to knowledge when they satisfy certain 
conditions. If the open theist adopts this view, she may be able to resist the argument that we can know things God can't. For it might be the case that, whenever we know that some future contingent is true, God has a credence in that future condition which satisfies the conditions for probabilistic knowledge. Then God's credence in that future contingent amounts to knowledge, just as we know the future contingent.

We take the main downside of the credence-only view to be that it denies the intuitive idea that God has beliefs. Not only is this idea natural, but, assuming humans have beliefs, it follows from plausible divine-human symmetry principles, mentioned above. That is, in the Judaeo-Christian tradition, God is a personal being with a mind, and we are made in God's image. If we have beliefs, this provides at least some reason to think God has beliefs. This may also be a downside for the knowledge-only view, discussed next, but the knowledge-only view can tell a principled story on which God has no mental representations at all - neither beliefs nor credences. It strikes us as odd to posit that God has mental representations, but no beliefs. This isn't a knockdown argument against the credence-only view, though, and, as we've explained, the credence-only view has other virtues - including fitting well with views on which God has non-extreme credences.

\section{The knowledge-only view}

The most radical view about divine beliefs and credences denies that God has either of them. Alston (1986) reminds us that, despite the popularity of the view that knowledge is unGettiered justified true belief, a notion of knowledge as direct awareness has an impressive philosophical pedigree as well. ${ }^{11}$ Drawing on this alternative tradition, Alston develops a view on which God is directly aware of, or is directly acquainted with, the facts that God knows. ${ }^{12}$ Alston contends that this is the most perfect way of knowing, and so it is the appropriate form of knowledge for God. ${ }^{13}$ But it doesn't involve mental representations at all. Alston suggests this view of divine knowledge excludes divine beliefs (ibid., 297-298); or, at the very least, it renders divine beliefs superfluous. For example:

A creature in our condition needs inner representations in order to be able to think about absent states of affairs, since the facts are rarely if ever directly present to our consciousness. But since God enjoys the highest form of knowledge He is never in that position, and so He has no need for inner representations that He can 'carry around with him' for use when the facts are absent. The facts are never absent from His awareness; thus it would be fatuous to attribute to Him any such mental map. When we have arrived at our destination we can fold the map away. (ibid., 299)

The main lesson Alston derives from these observations is that God has no beliefs. He does not discuss credences. But if credences are representational states, then it follows from Alston's remarks that God has no credences. And even if credences are not representational states, it seems perfectly coherent and even natural to conjoin Alston's view that God has no beliefs with the thesis that God has no credences.

Alston argues that his account of divine knowledge is helpful for solving two traditional problems about omniscience: the problem of freedom and foreknowledge, and knowledge of indexicals. ${ }^{14}$ We might add that Alston's account makes it easy to explain how God can know the various facts which theists claim that God knows. Here are two examples. First, if there are Platonic abstract objects, then presumably God has knowledge of them. But Baras (2017) argues that God cannot have such knowledge because abstract objects are causally inert, and so there cannot be causal connections between abstract objects and God's mind which ensure that God's beliefs about abstract objects are reliably 
formed. However, on Alston's account, God has no beliefs, and there is instead a direct acquaintance relation (which is arguably non-causal) between God's mind and facts about abstract objects. ${ }^{15}$ So the worry about the reliability of God's beliefs about abstract objects is bypassed. Second, Molinists claim that God knows true counterfactuals of freedom. A number of philosophers have challenged Molinists on this point, arguing that there is no way that God could come by this knowledge even if some counterfactuals of freedom are true (a matter of considerable controversy). But Mooney (2020) uses Alston's account of divine knowledge to rebut these objections. He proposes that God can simply be directly acquainted with the fact that a given counterfactual of freedom instantiates the property being true. ${ }^{16}$

However, Alston's view of divine knowledge has its critics. In an early response to Alston, Hasker (1988) argues that, if God is temporal, then God can only be directly aware of or acquainted with facts that are present. Past and future facts do not exist, and God can't be directly aware of what is not there for God to be directly aware of. So for knowledge of the past and future, God needs mental representations. And if God has mental representations corresponding to past and future facts, then God also has mental representations corresponding to present facts.

There are ways to resist Hasker's objection. If eternalism is true, then past and future facts exist, and so God can be directly aware of them just as God is directly aware of present facts. But what if eternalism is false? Eternalism's main rival, presentism, denies that past and future entities exist. However, even if past and future facts do not exist, present facts that consist in past-tensed and future-tensed propositions instantiating truth exist. So God could be directly acquainted with, say, the presently existing fact that the proposition Abraham Lincoln was tall instantiates the property being true. ${ }^{17}$ This would give God exhaustive knowledge of the past and the future by means of direct awareness. Therefore it is not clear that Hasker's objection is successful. ${ }^{18}$

One could also endorse an open theist variant of this proposal. Perhaps there are no future contingent propositions that instantiate being true (as on open-future open theism), or perhaps there are such propositions but God can't be directly aware of them because God can't know them (as on other versions of open theism). Even so, God will be directly aware of facts about the non-extreme objective chances of those future contingents. This would be a knowledge-only analogue of the view that God has non-extreme credences in future contingents.

Mavrodes (1988) raises a different objection. Views like Alston's, where God has direct contact with the facts that God knows, entail that God's knowledge depends on those facts. God knows that hippos are fat because hippos are fat. But one might worry, as Mavrodes does, that dependence of this sort is an imperfection: 'Everything about God should be completely independent of the world of things that are not divine' (ibid., 359). ${ }^{19}$ Mavrodes suggests an alternative, inferential account of divine knowledge which (allegedly) does not entail that God's knowledge depends on the world, and it is hard to see how an inferential account of divine knowledge could get by without beliefs or something like beliefs.

This objection can be challenged on at least two grounds. First, on Alston's view, God's existence is not dependent on facts outside God, nor is any intrinsic feature of God dependent on those facts, including whatever it is in virtue of which God is disposed to know every fact via direct awareness. Maybe this sort of independence is all that is required of a perfect being. Second, God's relation to the world might take the teeth out of this objection. If God's knowledge depends on the world, but the world in turn depends on God or God's creative activity, then God's knowledge does not depend on any absolutely fundamental or independent thing outside of God or God's activity. ${ }^{20}$ And if the world is a part of God, as the panentheist believes, then dependence on the 
world just is dependence on God. So it's not clear that Mavrodes's objection succeeds either.

More recently, Dickinson (2019) has raised yet another objection to Alston's view. He argues that cases of direct awareness like infant perception, or seeing something in one's peripheral vision, show that direct awareness is not enough for knowledge. In these cases, the subject seems to be directly, albeit dimly, aware of something in their environment, but does not have knowledge of what they are aware of. Dickinson says: 'It seems we must conceptualize (or notice, or form thoughts about) the facts of which we are directly aware for them to become epistemically relevant to us' (Dickinson (2019), 6; italics in original). However, Saeedimehr (2020) responds that direct awareness is insufficient for knowledge in these cases due to human limitations. Our direct awareness of facts is mediated by our imperfect sensory organs, and so it is not the most perfect form of direct awareness. God has the most perfect form of direct awareness, and that is - or at least might be - sufficient for knowledge.

It's difficult to adjudicate this issue. Since all of our awareness of facts is mediated by our imperfect faculties, we don't know what it's like to have perfect direct awareness of some fact. And so we can't simply reflect on what perfect awareness is like and consult our intuitions about whether it suffices for knowledge. But one thing is clear: the view that God has neither beliefs nor credences remains a live option.

\section{Conclusion}

We have now surveyed seven views on divine beliefs and credences. First, there is the belief-only view. The main problem for that view is that it fails to specify God's precise amount of evidence for the propositions God believes. The next view is the belief-and-credence view, which divides into four views: the divine belief-first view, the divine threshold view (where $t<1$ ), the divine belief-is-credence-1 view, and divine dualism. The problem for both dualism and the threshold view is that, if God has non-extreme credences in things God believes, God risks having a false belief, and this compromises omniscience. Further, if God has only extreme credences, then a feature of each view appears superfluous - either the existence of beliefs at all (for dualism) or the fact that the threshold is less than 1 (for the threshold view). We thus conclude that the belief-first view and the belief-is-credence-1 view are most promising.

We then considered two additional views: sixth, the credence-only view and seventh, the knowledge-only view. While the credence-only view has some interesting considerations in its favour - including avoiding the implication that God's non-extreme credences risk God's having false beliefs, and being able to explain divine knowledge by borrowing from Moss's account - its main downside is that it posits that God has mental representations but no beliefs, which may be odd. Finally, we think the knowledge-only view is a serious contender - although it somewhat counterintuitively denies that God has mental representations at all, it also helps to solve some problems about omniscience. While we won't conclude in favour of a single view, we hope to have highlighted some of the most promising views. We think that much more work should be done on divine mental states, specifically divine credences, and we hope this article is a useful foray into this important but underexplored topic.

Acknowledgements. Both authors contributed equally to this article, and were equally involved in every stage of its conception and writing. Thanks to three anonymous referees, Mohammad Saleh Zarepour, Dominik Kauss, and Nevin Climenhaga for useful comments on an earlier draft, and to audiences at the Lisbon LanCog Research Group and the Goethe University in Frankfurt for helpful questions and comments. 


\section{Notes}

1. Some epistemologists treat credences as a mental state on a par with beliefs. These epistemologists often assume that credences are a precisified version of our everyday notion of confidence (see Schupbach (2018), 191, Moon (2019), 276-277). Others treat credences as a modeling tool, useful for research in artificial intelligence, computer science, and representing and predicting human behaviour. Many in this latter camp would be hesitant to say that credences are a mental state, at least in the way that beliefs are. While we'll generally proceed by assuming that credences are mental states, we also don't think our arguments hang on this, and many of our conclusions about God's credences still apply if credences are a way of modelling God rather than mental states ascribed to God.

2. The concept of credence grew out of work on subjective probability. Some important historical work on credence includes Ramsey (1926, 166ff.), Carnap (1962, 305), Jeffrey (1965), and de Finetti (1974). For an excellent paper on the nature of credence, see Eriksson and Hájek (2007). For an overview of the relationship between belief and credence, see Jackson (2020-a).

3. On this point we side with Murphy (2017, ch. 1) and against Nagasawa (2008), (2017).

4. For a summary of some of the main views, see Ichikawa and Steup (2017).

5. Arnold (2015) suggests applying Williamson's knowledge-first view to God in the context of the debate about divine foreknowledge and human freedom.

6. Representatives of open theism include Hasker (1989), Boyd (2001), van Inwagen (2008), Swinburne (2016), and others.

7. As an anonymous referee points out, the belief-first view is compatible with a threshold view. Consider a divine belief-first view on which God's having a high credence in $p$ just is God's believing that $p$ is sufficiently probable. One could affirm both this and the threshold view if they affirmed that God's believing $p$ is sufficiently probable entails God's believing $p$. However, this view runs into the worries for the credence-first threshold view: God's beliefs are either superfluous, or God risks having a false belief. Thus, if God has a non-extreme credence in $p$, divine belief-firsters should deny that God also flat-out believes $p$. For discussion of the belief-first threshold view, see Moon and Jackson (2020, n. 7) and Weisberg (2020, n. 8).

8. According to Stewart (2019), the open theist John Sanders, in conference comments, endorsed the view that God believes a proposition only if God has $100 \%$ confidence in that proposition.

9. Thanks to Nevin Climenhaga for a comment which inspired this objection.

10. The idea is not that we cannot engage in probabilistic reasoning when deciding whether to blame someone. The cases of interest are ones in which you believe someone is guilty and all the relevant evidence you have is statistical evidence. For further discussion, see Staffel (2015), Bolinger (2020), and Jackson (2020-b).

11. See Price (1935), Antognazza (2015, 165-172), Idem (2021), and Climenhaga (Forthcoming). For a historical overview of this view of knowledge, see Ayers and Antognazza (2019).

12. Dickinson (2019) argues in favour of interpreting Alston's model as an acquaintance model.

13. Interestingly, Mavrodes $(1988,359)$ reports a similar intuition, but resists it.

14. Hasker (1988) demurs on the point about foreknowledge.

15. For other accounts of God's knowledge of the Platonic realm, see Brenner (2021) and Knowles (2021).

16. However, Alston's account is not the only one with these advantages. Brenner (2021) notes that his grounding account of God's knowledge can explain how God knows facts about abstract objects, counterfactuals of freedom, and future contingents, and claims this as an advantage of his view.

17. Cf. 'How Could God Know the Future? William Lane Craig \#2' Closer to Truth interview clip (Robert Lawrence Kuhn, interviewer). <https://www.closertotruth.com/series/how-could-god-know-the-future\#video-2056>.

18. For another acquaintance account of God's knowledge of past and future facts, see Dickinson (2019: 11-13). 19. Mavrodes (1988) also notes that we sometimes have the intuition that reason-based knowledge is superior to direct knowledge.

20. See Brower (2009) for discussion of this move.

\section{References}

Alston W (1986) Does God have beliefs? Religious Studies 22, 287-306.

Antognazza MR (2015) The benefit to philosophy of the study of its history. British Journal for the History of Philosophy 23, 161-184.

Antognazza MR (2021) The distinction in kind between knowledge and belief. Proceedings of the Aristotelian Society 120, 277-308.

Arnold A (2015) Knowledge first and ockhamism. Oxford Studies in Philosophy of Religion 6, 1-20. 
Ayers, M and Antognazza MR (2019) Knowledge and belief from Plato to Locke. In Ayers M (ed.), Knowing and Seeing: Groundwork for a New Empiricism. Oxford: Oxford University Press, pp. 3-34.

Baras D (2017) A reliability challenge to theistic platonism. Analysis 77, 479-487.

Bennett K (2017) Making Things Up. Oxford: Oxford University Press.

Bolinger RJ (2020) The rational impermissibility of accepting (some) racial generalizations. Synthese 197, $2415-2431$.

Boyd G (2001) The open-theism view. In Beilby J and Eddy P (eds), Divine Foreknowledge: Four Views. Downers Grove, IL: InterVarsity Press, pp. 13-47.

Bradley S (2019) Imprecise probabilities. In Zalta EN (ed.), The Stanford Encyclopedia of Philosophy. https://plato. stanford.edu/entries/imprecise-probabilities/.

Brenner A (2021) How does God know that 2+2=4? Religious Studies 57, 301-316.

Brower J (2009) Simplicity and Aseity. In Flint T and Rea M (eds), The Oxford Handbook of Philosophical Theology. Oxford: Oxford University Press, pp. 105-128.

Brown J (2008) Knowledge and Practical Reason. Philosophy Compass 3, 1135-52.

Buchak L (2014) Belief, credence, and norms. Philosophical Studies 169, 1-27.

Carnap R (1962) Logical Foundations of Probability. Chicago: The University of Chicago Press.

Christensen D (2004) Putting Logic in its Place: Formal Constraints on Rational Belief. Oxford: Oxford University Press.

Climenhaga N (Forthcoming) How infallibilists can have it all. The Monist.

De Finetti B (1974) Theory of Probability, vol. 1. New York: Wiley.

DeRose K (1995) Solving the skeptical problem. The Philosophical Review 104, 1-52.

Dickinson T (2019) God knows: acquaintance and the nature of divine knowledge. Religious Studies 55, 1-16.

Easwaran, K (2015) Formal epistemology. The Journal of Philosophical Logic 44, 651-662.

Eriksson L and Hájek A (2007) What are degrees of belief? Studia Logica 86, 183-213.

Frankish K (2009) Partial belief and flat-out belief. In Huber F and Schmidt-Petri C (eds), Degrees of Belief. New York: Springer, pp. 75-96.

Greco D (2015) How I learned to stop worrying and love probability 1. Philosophical Perspectives 29, $179-201$.

Hasker W (1988) Yes, God has beliefs! Religious Studies 24, 385-394.

Hasker W (1989) God, Time, and Knowledge. Ithaca, NY: Cornell University Press.

Hawthorne J (2004) Knowledge and Lotteries. Oxford: Oxford University Press.

Holton R (2014) Intention as a model for belief. In Vargas M and Yaffe G (eds), Rational and Social Agency: Essays on the Philosophy of Michael Bratman. Oxford: Oxford University Press, pp. 12-33.

Horgan T (2017) Troubles for Bayesian formal epistemology. Res Philosophica 94, 233-255.

Ichikawa JJ and Steup M (2017) The analysis of knowledge. In Zalta EN (ed.), The Stanford Encyclopedia of Philosophy, https://plato.stanford.edu/entries/knowledge-analysis/.

Jackson E (2019) How belief-credence dualism explains away pragmatic encroachment. The Philosophical Quarterly 69, 511-533.

Jackson E (2020a) The relationship between belief and credence. Philosophy Compass 15, 1-13.

Jackson E (2020b) Belief, credence, and evidence. Synthese 197, 5073-5092.

Jackson E (Forthcoming) Why credences are not beliefs. Australasian Journal of Philosophy. doi: 10.1080/ 00048402.2020 .1867210 .

Jackson E (2021) Settling the unsettled: roles for belief. Analysis 81(2), 359-368.

Jeffrey R (1965) The Logic of Decision. Chicago, IL: University of Chicago Press.

Kaplan M (1996) Decision Theory as Philosophy. Cambridge: Cambridge University Press.

Knowles R (2021) The uncanny accuracy of God's mathematical beliefs. Religious Studies 57, 333-352.

Kvanvig J (1986) The Possibility of an All-Knowing God. London: Palgrave Macmillan.

Lee M (2017) On the arbitrariness objection to the threshold view. Dialogue 56, 143-158.

Lewis D (1980) A subjectivist's guide to objective chance. In Jeffrey R (ed.), Studies in Inductive Logic and Probability II. Berkeley: University of California Press, pp. 263-293.

Mavrodes GI (1988) How does God know the things He knows? In Morris TV (ed.), Divine and Human Action: Essays in the Metaphysics of Theism. Ithaca: Cornell University Press, pp. 345-361.

Moon A (2019) A new puzzle about belief and credence. The Canadian Journal of Philosophy 49, 272-291.

Moon A and Jackson E (2020) Credence: a belief-first approach. The Canadian Journal of Philosophy 50, 652-669.

Mooney J (2020) How God knows counterfactuals of freedom. Faith and Philosophy 37, 220-229.

Moss S (2013) Epistemology formalized. The Philosophical Review 122, 1-43.

Moss S (2018) Probabilistic Knowledge. Oxford: Oxford University Press.

Murphy M (2017) God's Own Ethics: Norms of Divine Agency and the Argument from Evil. Oxford: Oxford University Press.

Nagasawa Y (2008) A new defense of perfect being theism. Philosophical Quarterly 58, 577-596.

Nagasawa Y (2017) Maximal God: A New Defence of Perfect Being Theism. Oxford: Oxford University Press. 
Price HH (1935) Some considerations about belief. Proceedings of the Aristotelian Society 35, 229-252.

Ramsey F (1926) Truth and probability. In Braithwaite RB (ed.), The Foundations of Mathematics and Other Logical Essays. London: Kegan, Paul, Trench, Trubner \& Co, pp. 156-198.

Ross J and Schroeder M (2014) Belief, credence, and pragmatic encroachment. Philosophy and Phenomenological Research 88, 259-288.

Saeedimehr M (2020) Divine knowledge as direct awareness: a defence of Alston. Religious Studies, doi: 10.1017/ S0034412519000787.

Schaffer J (2015) What not to multiply without necessity. Australasian Journal of Philosophy 93, 644-664.

Schupbach J (2018) Troubles for Bayesian formal epistemology? A response to Horgan. Res Philosophica 95, $189-197$. Shear T and Fitelson B (2019) Two approaches to belief revision. Erkenntnis 84(3), 487-518.

Staffel J (2015) Beliefs, buses, and lotteries: Why rational belief can't be stably high credence. Philosophical Studies $173,1721-1734$.

Staffel J (2019) How do beliefs simplify reasoning? Noûs 53, 937-962.

Stewart RB (2019) On open theism either God has false beliefs or I can know something God cannot. In Arbour B (ed.), Philosophical Essays Against Open Theism. New York, NY: Taylor \& Francis, pp. 110-118.

Sturgeon S (2020) The Rational Mind. Oxford: Oxford University Press.

Swinburne R (2016) The Coherence of Theism: Second Edition. Oxford: Oxford University Press.

Tang WH (2015) Belief and cognitive limitations. Philosophical Studies 172, 249-60.

van Inwagen P (2008) What does an omniscient being know about the future? Oxford Studies in Philosophy of Religion 1, 216-230.

Weisberg J (2015) You've come a long way, Bayesians. Journal of Philosophical Logic 44, 817-834.

Wierenga E (2011) Omniscience. In Flint TP and Rea MC (eds), The Oxford Handbook of Philosophical Theology. Oxford: Oxford University Press, pp. 129-144.

Weisberg J (2020) Belief in psyontology. Philosophers' Imprint 20, 1-27.

Williamson T (2000) Knowledge and its Limits. Oxford: Oxford University Press.

Zagzebski L (2008) Omnisubjectivity. Oxford Studies in Philosophy of Religion 1, 231-247.

Cite this article: Jackson E, Mooney J (2022). Probing the mind of God: divine beliefs and credences. Religious Studies 58, S61-S75. https://doi.org/10.1017/S003441252100041X 